\title{
Effect of microalga-based diet on oxidative stress enzymes of African catfish, Clarias gariepinus
}

\author{
Shaishav Sharma $\cdot$ Ekta Shah $\cdot$ Deepti Davla $\cdot$ Gaurav Dixit · \\ Aesha Patel $\cdot$ Adepu Kiran KumarD
}

Received: 14 March 2019/Accepted: 30 October 2019/Published online: 11 November 2019

(C) The Author(s) 2019

\begin{abstract}
Here an indigenously isolated microalgal strain Ascochloris spp. cultivated in synthetic medium was evaluated as an aquaculture feed supplement. The daily dietary supplement includes microalgal feed (AF) and commercial diet feed (CF) (as control), respectively. These diets were fed separately to the juvenile Clarias gariepinus fishes $(n=4)$ under controlled conditions for an experimental period of 100 days. The protein, glycogen and lipid contents in the muscle extracts were found to be marginally higher in fishes that were fed with CF than AF diet. Similarly, CF fishes showed significantly higher glutathione-s-transferase, catalase, superoxide dismutase, and lipid peroxidase activities, except glutathione content. Zero mortality of the fishes with no significant difference in the overall body mass with the two dietary supplements strongly suggests that algal biomass could supplement the requisite nutrients for their metabolic activities. This preliminary investigation helps in exploring algal biomass as a potential alternative feed additive in the aquaculture industry.
\end{abstract}

Keywords Aquafeed $\cdot$ Aquaculture $\cdot$ Microalgae $\cdot$ Oxidative enzymes

\section{Introduction}

Aquaculture industry is one of the rapidly growing sectors recording an annual growth rate of $8.8 \%$ in past three decades. Fishmeal and fish oil are the most essential constituents of the aqua feed that contributes to the increasing costs and sustainability of aqua-industry. Commonly fishmeal is obtained by milling and drying of the whole fish and/or its remains, which is mostly governed by the seasonal catches of the fishes. Moreover, fish supply and climate changes are the two major hindering factors for fishmeal production and are threat for long-term sustainability. It was estimated that total marine catches is predicted to decline drastically to 5 million metric ton by the end of year 2020 (FAO 2012, 2018). Globally such alarming need enforces the aquaindustries for finding partial and complete fishmeal replacement. This have led to an extensive use of plantbased nutrient sources such as cereals, oilseed meals, pulses and protein concentrate meals (groundnut, peanut, cottonseed, sunflower seed, palm kernel, coconut, rapeseed, soybean protein concentrate, wheat gluten, corn

Electronic supplementary material The online version of this article (https://doi.org/10.1007/s40071-019-00245-z) contains supplementary material, which is available to authorized users.

S. Sharma · E. Shah · D. Davla · G. Dixit · A. Patel · A. K. Kumar $(\bowtie)$

Bioconversion Technology Division, Sardar Patel Renewable Energy Research Institute, Near BVM Engineering College,

Vallabh Vidyanagar, Post box No. 2, Anand, Gujarat 388120, India

e-mail: kiranbio@gmail.com 
gluten, etc.). Moreover, plant-diets must ensure accurate inclusion levels for metabolic synthesis of essential amino acids in these alternative diets supplemented fishes (Olsen and Hasan 2012). Recently, insects are being used as an excellent diet sources for fishes and are preferred as potential choices for fishmeal replacement. This includes locusts, common houseflies, mosquitoes, superworms, grasshoppers, termites, yellow mealworms, Asiatic rhinoceros beetles, domesticated silkworms and black soldier flies, respectively. However, chitin digestibility and bioaccumulation of insecticides in the fish body poses severe hurdles during these dietary inclusions (Henry et al. 2015).

Recently, microalgae have garnered interest in food and nutrition due to the presence of high amounts of proteins, vitamins, polyunsaturated fatty acids and antioxidants, respectively. Besides, microalgae are used in wide range of applications in renewable energy and nutraceutical sectors due to the generation of value-added products. Microalgae are fast-growing photosynthetic organisms which can produce a theoretical yield of approximately $77 \mathrm{~g} \mathrm{~m}^{-2}$ day $^{-1}$ on dry biomass basis which accounts for $\sim 280$ ton ha $^{-1}$ year $^{-1}$. About 5000 metric ton of algal biomass is processed annually in the US alone accounting for a turnover of 1.25 billion USD year (Khan et al. 2018). In contrast to the production and maintenance cost of fishmeal, microalgae require fewer resources and are extremely valuable. Arable land and freshwater are not a pre-requisite for microalgae cultivation as it posses the flexibility to grow in high salinity lands, wastewaters, industrial effluents and a wide variety of mediums rendering high algal yield. Apart from this, microalgal cultivation significantly reduces the greenhouse gas emissions (Park and Lee 2016). Besides, the conventional sources like soya, egg, rice, milk, meat and baker's yeast that are used in fish diets usually comprises up to $47 \%$ ( $w / w$ ) protein content, whereas, microalgal species are known to contain very high protein contents up to $71 \%$ ( $w / w)$, respectively (Chacon-Lee and Gonzalez-Marino 2010). Along with this, the amino acid contents of almost all the microalgal species are in accordance with the levels present in other food proteins (Becker 2004).

Although to certain extent, there are several reports on the applicability of microalgal biomass as an aqua feed supplement. It is a well known fact that microalgae are regarded as an excellent source of antioxidants, and its consumption helps the aquatic organisms to cope up with the oxidative stress generated due to metabolic and other factors. Cahu et al. (1998) reported that feeding algae to Dicentrarchus labrax in larval stage significantly improved the digestive functions in the intestinal and pancreas. Similarly, effects on addition of sea weeds viz., Spirulina spp., Chlorella spp. and Azolla spp. as a partial fish meal replacement on Macrobrachium rosenbergii were studied and its non-toxicity on postlarval stages of fishes were reported (Radhakrishnan et al. 2014). Also, products derived from algae like rosamin and verdemin when added to the fish feed has significantly increased omega-3 long chain polyunsaturated fatty acid (PUFA) content in Salmo salar (Norambuena et al. 2015). Other than aquatic animals, cross-bred dairy goats supplemented with Chlorella vulgaris exhibited progressive formation of trans-11 C18:1 and monounsaturated fatty acids (MUFA) compared to the control diets (Tsiplakou et al. 2017). Furthermore, anti-proliferative effects of bioactive carotenoids extracted from Chlorella ellipsoidea and Chlorella vulgaris on human colon cancer cells were reported suggesting microalgae as a potential therapeutic agent (Cha et al. 2008).

Recently, we have identified an indigenously isolated microalgal strain, Ascochloris spp. from dairy effluent contaminated water samples collected from one of the largest dairy industry in India, AMUL (Anand Milk Union Limited), located in Anand district of Gujarat, India. Comprehensive studies on the microalgal growth properties, biomass and lipid productivities were reported earlier (Kumar et al. 2018). Since the acceptability and feasibility of any metabolic diet is determined by physical growth, biochemical and enzymatic indices of an organism, a preliminary assessment of such indices were performed on African catfish, Clarias gariepinus, to evaluate whether the Ascochloris spp. may be used as a partial replacement of conventional aquafeeds. Clarias spp. belongs to the family Claridae and is a popular fish species for aquaculture business in Southeast Asian countries. Also, owing to its high growth rate, disease resistance, fecundity and stress handling, it has a high commercial significance worldwide (Muchlisin and Siti-Azizah 2010).

\section{Materials and methods}

All the chemicals and reagents used in the study were of analytical grade and procured from Sigma (St. Louis, MO, USA), Himedia (Himedia Laboratories Pvt Ltd., Mumbai, India) and Loba Chemie (Loba Chemie Pvt. 
Ltd., Mumbai, India), respectively. The glass tanks used for maintaining fishes for the experimental period were procured locally.

Microalgae cultivation

All the experiments in the current study were performed using the microalgal strain, Ascochloris spp. as the algal feed. The microalga was grown in synthetic TAP (Tris-Acetate-Phosphate) medium under controlled conditions, i.e., light:dark cycle of $16: 8 \mathrm{~h}$ at a constant temperature of $25 \pm 1{ }^{\circ} \mathrm{C}$ with light intensity between ranging between 3366 and $3978 \mathrm{~W} / \mathrm{m}^{2}$ for a period of 5-17 days in a growth chamber (Supplementary Fig. 2c). The microalgal biomass was harvested using centrifugation at $10,000 \times g$ for $10 \mathrm{~min}$ and then dried at $\leq 50{ }^{\circ} \mathrm{C}$ until the moisture content reached $\leq 5 \%$ (Supplementary Fig. 2d, e) (Kumar et al. 2018). In order to avoid minimal cell damage necessary precautions were taken during the entire process of microalgal cultivation to algal feed preparation. Further, microscopic analysis and chlorophyll content in the cell-free supernatant showed no cell disruption (Supplementary Fig. 2a).

In this study, we have analyzed the biochemical and enzymatic responses of Clarias gariepinus with two different dietary supplements, i.e., (a) algae fed (AF) and (b) commercial feed fed (CF), respectively. All the fish feeding experiments were carried out for a period of 100 days in the algal laboratory at Bioconversion technology division at Sardar Patel Renewable Energy Research Institute, Gujarat, India. The present study was undertaken with the approval from the institutional ethical committee members. The microalga, Ascochloris spp. used as an algal feed in the present study was isolated, morphologically and genetically identified and reported earlier by us (Kumar et al. 2018). Juvenile Clarias gariepinus fishes were procured from the local farm and acclimatized in the laboratory for 2 weeks before starting the feeding experiments. All the test fishes were selected based on their similar body weight (160-170 g) and 25-30 cm length, respectively. Fish feed experiments were conducted in $55 \mathrm{~L}$ glass water tanks $(60 \mathrm{~cm} \times 30 \mathrm{~cm} \times 38 \mathrm{~cm})$ with each tank comprising four fishes $(n=4)$. Each tank was provided with an aerator rod attached with a submergible air pump for uniform aeration throughout the tank. Fishes in tank (a) were fed with commercial feed, while tank (b) with alga feed, respectively.

Commercial feed (Make: Optimum aquarium food, Thailand), procured from local vendor, consist of $28 \%$ $(w / w)$ crude protein, $3 \%(w / w)$ crude fat, $4 \%(w / w)$ crude fiber and $10 \%(w / w)$ moisture was used as control feed. While, dried algal biomass with moisture content $\pm 5 \%$ was used as algal feed. No post-processing of the feed materials was involved. Fishes in both the tanks were fed twice a day with dried algal biomass and commercial feed, respectively, at $2 \%(w / w)$ of the fish body weight for a period of 100 days (Supplementary Data 1). The tanks were maintained at $\mathrm{pH} 8.0-8.5$ and temperature $30-35{ }^{\circ} \mathrm{C}$, respectively, by replacing the tank water with nearly $50 \%(\mathrm{v} / \mathrm{v})$ of clean water every day. Body weight measurements of fishes were taken every fortnight. At the end of the experiment, the fishes were euthanized with Tricaine methane sulphonate (MS-222) followed by decapitation as described by Close et al. (1996). Muscle tissues were carefully excised under sterile conditions from the dorsal region using a sterile scalpel and approximately $1 \mathrm{gm}$ each of sample were taken for pulverization in liquid nitrogen. All the samples were stored at $-80{ }^{\circ} \mathrm{C}$ for further biochemical analysis.

Compositional analysis: the compositional analysis of the microalgal biomass was evaluated following the NREL laboratory analytical procedure (Laurens 2015). Ash content of the microalgal biomass was determined using dry oxidation method in a muffle furnace at $575{ }^{\circ} \mathrm{C}$. Equation (1) was used for measuring percent ash content where $\mathrm{DW}_{\text {sample }}$ is the weight of the microalgal biomass on dry basis:

$$
\text { Ash } \%=\frac{\left(\text { weight }_{\text {crucible }+ \text { ash }}-\text { weight }_{\text {crucible }}\right)}{\text { DW }_{\text {sample }}} \times 100 .
$$

Protein content $(\%, w / w)$ in the microalgae biomass was determined using Kjeldahl method and was calculated using Eq. (2), where ' $\% N$ ' is elemental nitrogen content and ' $N$ factor' is a specific factor determined for algae (4.78).

$$
\text { Protein } \%=\% N \times N_{\text {factor }} \text {. }
$$


Lipid quantification $(\%, w / w)$ was performed using Bligh and Dyer method (1959) where chloroform/ methanol/water ratios were maintained at 1:2:0.8, respectively. Total carbohydrate content in the microalgal biomass was determined using two-step acid hydrolysis method where sulphuric acid breakdown the polysaccharides into monosaccharides and were quantified using HPLC (Schimadzu LC 2010C). The \% carbohydrate was determined using Eq. (3):

$$
\text { Carbohydrate } \%=\left(\frac{\text { total monosaccharides }}{\mathrm{DW}_{\text {sample }}}\right)-\operatorname{starch} \% \times 100 \text {. }
$$

Moisture content (\%) in the microalgal biomass was calculated using oven-dry method, where $100 \mathrm{mg}$ of wet alga was taken in a pre-weighed ceramic crucible and dried at $105{ }^{\circ} \mathrm{C}$ in a vacuum oven. Finally the $\%$ moisture was determined using Eq. (4).

$$
\text { Moisture } \%=\frac{\left(\text { weight }_{\text {wetbiomass }}-\text { weight }_{\text {drybiomass }}\right)}{\text { weight }_{\text {wetbiomass }}} \times 100 .
$$

Biochemical analysis: protein, glycogen and lipid determination

The tissue extractives from the fishes were obtained by finely crushing $0.5 \mathrm{~g}$ of muscle tissue in a specific extraction buffer that was described below for each individual. The tissue slurry was then sonicated for $20 \mathrm{~s}$ and centrifuged at $10,000 \mathrm{rpm} \times g$ for $20 \mathrm{~min}$ to obtain clarified tissue extract. All the clarified extracts were stored at $-20{ }^{\circ} \mathrm{C}$ until further biochemical analysis. The muscle protein and carbohydrates were extracted in sodium phosphate buffer $(50 \mathrm{mM}, \mathrm{pH} 7.0)$ containing $1 \mathrm{mM}$ dithiothreitol, $1 \%(v / v)$ Triton-X 100, $1 \mathrm{mM}$ ethylenediaminetetraacetic acid. The protein content was quantified spectrophotometrically using Bradford's method (Bradford 1976). Bovine serum albumin was used as external standard and the absorbance was recorded at $550 \mathrm{~nm}$ in microplate reader (Biotek, Synergy HT). Total glycogen content was determined using phenol-sulphuric acid method (Dubois et al. 1956). Dextrose was used as a standard reducing sugar and the absorbance was recorded at $490 \mathrm{~nm}$. Lipid extraction from the muscle tissues was performed following Folch's method (Folch et al. 1957). Briefly, the muscle tissue was crushed in chloroform/methanol (2:1) and the two layers were separated by a separating funnel. The organic layer containing the lipids were collected and subjected to vacuum rotary evaporation method (Heildoph, Hei-vap). The lipid content was determined gravimetrically. Final results were expressed in $\mathrm{mg} \mathrm{g}^{-1}$ dry weight of the tissue.

Determination of oxidative stress enzymes

\section{Glutathione (GSH) assay}

For glutathione (GSH) determination, the muscle tissue was pulverized in 5\% sulfosalicylic acid and the supernatant was separated by centrifugation at $10,000 \times g$ for $20 \mathrm{~min}$. The GSH activity was estimated by enzymatic recycling method following the protocol described by Akerboom and Sies (1981). Briefly, $1 \mathrm{~mL}$ of potassium phosphate buffer $(\mathrm{pH} 7.0)$ containing reduced glutathione $(0.5-2 \mathrm{nM})$, NADPH $(50 \mu \mathrm{L}$ of $\left.4 \mathrm{mg} \mathrm{mL}^{-1}\right), 5,5^{\prime}$-dithiobis(2-nitrobenzoic acid) $\left(20 \mu \mathrm{L}\right.$ of $\left.1.5 \mathrm{mg} \mathrm{mL}^{-1}\right)$ was added to the muscle tissue extracts and the rate of reaction was recorded at $412 \mathrm{~nm}$ over a period of $5 \mathrm{~min}$. Glutathione reductase $(20 \mu \mathrm{L}$ of $6 \mathrm{U} \mathrm{mL}^{-1}$ ) was used as control enzyme. The GSH activity was expressed as nmoles $\mathrm{mg}^{-1}$ of protein of the sample.

\section{Glutathione-s-transferase (GST) assay}

$0.5 \mathrm{~g}$ of the muscle tissue was crushed in $0.1 \mathrm{M}$ sodium phosphate buffer, $\mathrm{pH}$ 6.0. The GST activity was determined using Habig's method (Habig et al. 1974) with minor modifications. The assay mixture consists of $100 \mathrm{mM}$ 1-chloro, 2,4-dinitrobenzene, $200 \mathrm{mM} \mathrm{L}$-glutathione (reduced) and $10 \mu \mathrm{L}$ of the tissue extract. A kinetic measurement for $5 \mathrm{~min}$ with an interval of $30 \mathrm{~s}$ was recorded at $340 \mathrm{~nm}(\varepsilon=9.6 \mathrm{mM})$ using UV 
visible spectrophotometer (Shimadzu UV-Vis spectrophotometer UV-1700). GST activity was expressed as $\mu \mathrm{mol} \mathrm{mL} \mathrm{min}^{-1}$ and $\mathrm{nmol} \mathrm{mg}{ }^{-1}$ of protein sample.

\section{Catalase assay}

$0.5 \mathrm{~g}$ of the muscle tissue was crushed in $50 \mathrm{mM}$ sodium phosphate buffer (pH 7.0) consisting $1 \mathrm{mM}$ EDTA. The catalase activity was determined by Beers and Sizer's method (1952). The assay mixture consists of $30 \mathrm{mM} 30 \% \mathrm{H}_{2} \mathrm{O}_{2}$ and $10 \mu \mathrm{L}$ enzyme extract. Absorbance was immediately recorded at $240 \mathrm{~nm}$ for 2 min on UV visible spectrophotometer (Shimadzu UV-Vis 1700 spectrophotometer). The rate of decomposition of $\mathrm{H}_{2} \mathrm{O}_{2}$ is directly proportional to the catalase activity. One unit of catalase activity is defined as the amount of enzyme required to decompose $1 \mu \mathrm{M} \mathrm{H}_{2} \mathrm{O}_{2}$. The enzyme activity was expressed as $\mathrm{U} \mathrm{mg}^{-1}$ of protein.

\section{Superoxide dismutase assay}

$0.5 \mathrm{~g}$ of the muscle tissue was crushed in $50 \mathrm{mM}$ potassium phosphate buffer $(\mathrm{pH} 7.0)$ containing $0.25 \mathrm{M}$ sucrose. The clear supernatant was collected by centrifugation at $10,000 \times g$ for $20 \mathrm{~min}$ and analyzed for superoxide dismutase (SOD) activity using xanthine/xanthine oxidase coupled reaction as described by McCord and Fridovich (1969). The kinetic measurements were recorded at $550 \mathrm{~nm}$ for $5 \mathrm{~min}$. The SOD activity was expressed as $\mathrm{U} \mathrm{mg}^{-1}$ of protein.

\section{Lipid peroxidise assay}

$0.5 \mathrm{~g}$ of the muscle tissue was crushed in $20 \%$ trichloroacetic acid using Potter-Elvehjem homogenizer. The extract was then centrifuged at $10,000 \times g$ for $20 \mathrm{~min}$ at $4{ }^{\circ} \mathrm{C}$ to obtain clear supernatant. Lipid peroxidise activity was determined using a fluorometric assay method described by Ohkawa et al. (1979), where thiobarbituric acid $(0.67 \%)$ was used as a substrate and 1,1,3,3-tetramethoxypropane as a standard. The chemical adduct was fluorometrically determined in a plate reader at $E_{\mathrm{x}} / E_{\mathrm{m}}=532 \mathrm{~nm} / 553 \mathrm{~nm}$, respectively. The lipid peroxidation levels were expressed in nmoles of malon dialdehyde per dry weight of the tissue.

Statistical analysis

All the experiments were conducted in triplicates and the data are presented as mean \pm SEM. One-way analysis of variance (ANOVA) was carried out using SigmaPlot ver. 14.0 software (SigmaPlot Inc, USA). The significant differences in the means between dietary treatments were evaluated by Tukey's multiple range test. Mean differences were considered significant at a $p$ value of $<0.05$.

\section{Results and discussion}

\section{Biochemical analysis}

It was reported that inclusion of fresh and marine water-grown microalgae in the fish diet had significantly contributed in improving the healthy nature of the aqua species and also enhanced the immune responses towards oxidative stress (Mustafa et al. 1995; Velasquez et al. 2016). In this study, supplementing the algal biomass as aquafeed had not shown any significant differences in the overall body weight, as compared to the commercial feed, i.e., AF vs CF, respectively (Fig. 1), and is in line with other reported data. However, lower protein content $\left(9.03 \pm 0.08 \mathrm{mg} \mathrm{g}^{-1}\right)$ and lipid accumulation $\left(20.78 \pm 0.5 \mathrm{mg} \mathrm{g}^{-1}\right)$ was observed in AF, whereas in CF, significantly higher protein $\left(13.20 \pm 0.13 \mathrm{mg} \mathrm{g}^{-1}\right)$ and lipid $\left(24.02 \pm 0.06 \mathrm{mg} \mathrm{g}^{-1}\right)$ contents were recorded (Fig. 2a). One of the possible reasons could be due to the difference in the nature of feeder and the feed. The feeder, Clarias gariepinus, is a carnivorous fish, while the feed, i.e., microalgae, is of plant origin. Secondly, in general, it is known that lower digestibility of the dietary fibers is common in carnivorous fishes. The fibrous nature of the feed is mainly due to the carbohydrates of the microalga which accounted for lower feed intake, i.e., $60 \pm 7 \%$ in AF as compared to $79 \pm 9 \%$ in CF. Supporting our experimental results, it 


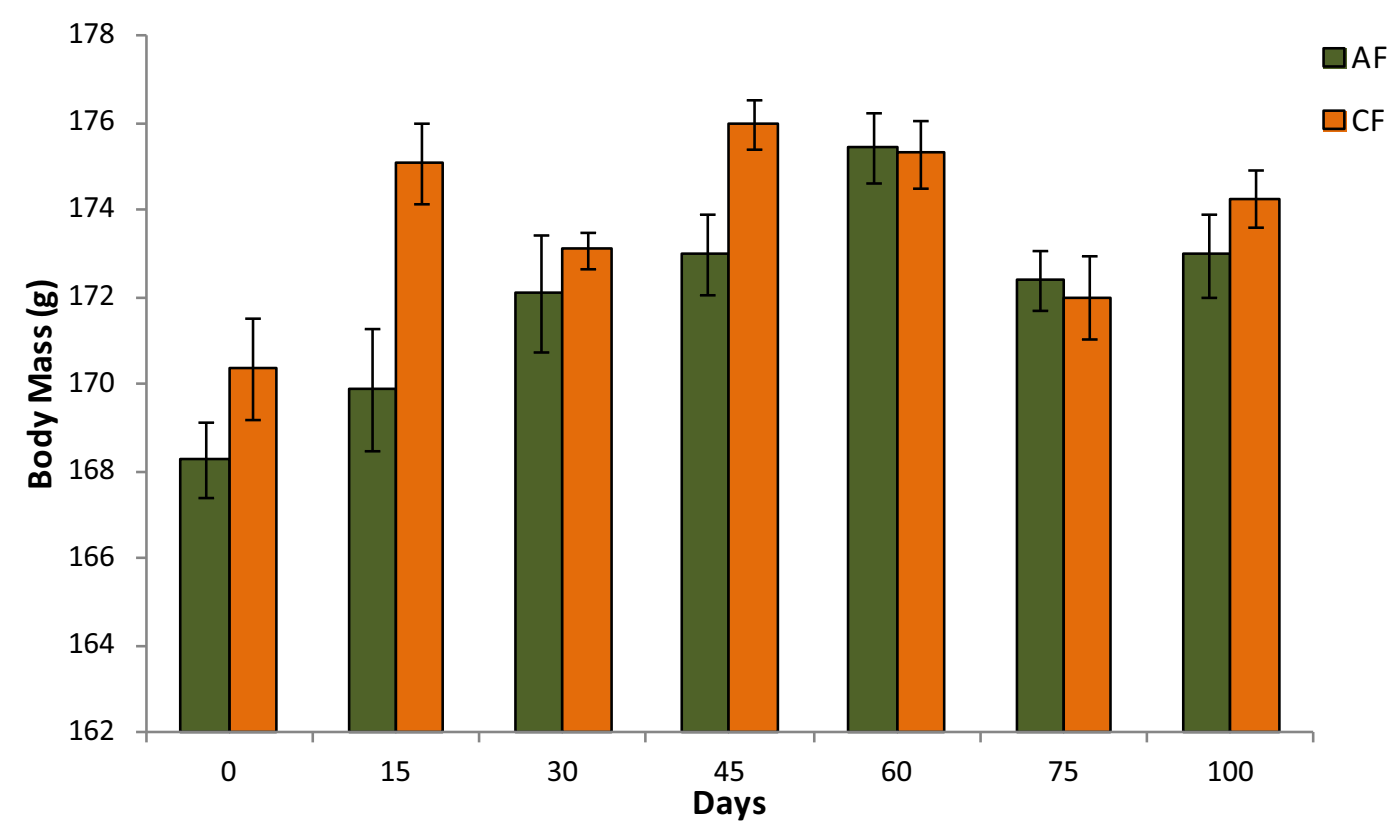

Fig. 1 Comparison of body mass of algae-fed fish (AF) and commercial feed-fed fish (CF) for the test period of 100 days. Body mass measurements were recorded every 15 days

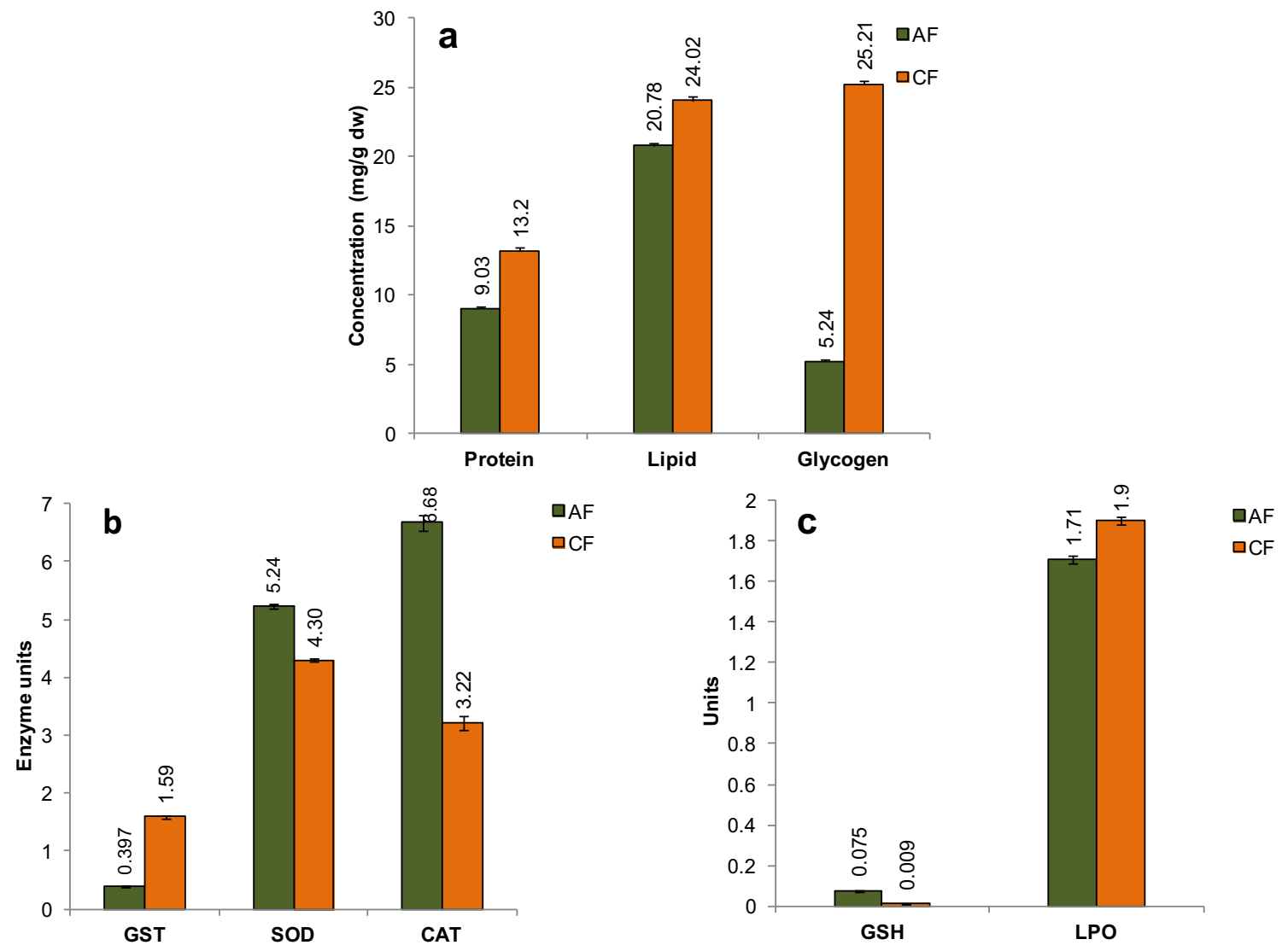

Fig. 2 Biochemical and enzymatic analysis of algae-fed fish AF and commercial feed-fed fish CF. a Protein, lipid and glycogen content, b enzyme activities, i.e., glutathione-s-transferase (GST), catalase (CAT), superoxide dismutase (SOD), c non-enzymatic antioxidant activity, i.e., lipid peroxidase (LPO) and glutathione (GSH). All the values are mean $\pm \operatorname{SEM}(n=4, p<0.05)$ 
was reported that carnivorous fishes have shown poor metabolizing ability when fed with carbohydrate enriched diet (Shimeno et al. 1978). The complexity of algal polysaccharides and anti-nutritional factors viz. tannins, saponins, protease inhibitors, lectins and phytic acid that are found in microalgal strains might have also contributed to the poor growth indices in the fishes (Davies et al. 1997; Francis et al. 2001). Hence, marginally lower muscle protein contents were observed in AF, Clarias gariepinus, and correlated to their lower consumption of the algal diet. Our results were also in line with other reported data where lower protein and lipid contents in alga fed fishes were recorded, like in Nile tilapia, Oreochromis niloticus, Mozambique tilapia, Oreochromis mossambicus and flat fish, Solea senegalensis fed on Hydrodictyon reticulaturn, Spirulina maxima and plant protein diet (Soyameal, soya protein concentrate, wheat gluten, etc.), respectively (Appler 1985; Olvera-Novoa et al. 1998; Valente et al. 2011). In another study, poor algal feed utilization, specific growth rate (SGR) and protein efficiency ratio (PER) was observed in when the feed was supplemented with Ulva lactuca and was reported recently by Abdel-Warith et al. (2016). Besides, rainbow trout, Oncorhynchus mykiss when fed with high carbohydrate diet exhibited stunted growth rate (Edwards et al. 1977). Our studies clearly suggests that microalga-based diet effect the physiological metabolism of Clarias gariepinus, especially the protein and lipid pathways, fatty acid biosynthesis, amino acid metabolism, intracellular protein transport and ribosome assembly (Panserat et al. 2008).

Enzymatic analysis

\section{Reduced glutathione}

Reduced glutathione (GSH) is one of the major non-enzymatic antioxidants. It plays a significant role in detoxification through chemical and enzymatic reactions (Ross 1988). The total glutathione contents in muscle

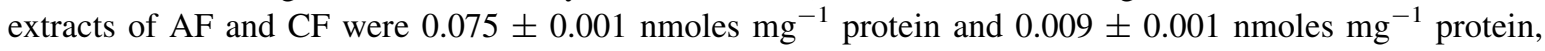
respectively (Fig. 2c). Higher amounts of GSH in AF clearly indicates an effective anti-oxidative nature by Clarias gariepinus, whereas lower levels in CF suggests depleted levels of GSH arising primarily due to oxidative stress conditions, thereby conversion of the reduced GSH to oxidative glutathione (GSSG). GSSG mainly involves in secondary reactions like conjugation, reduction, and interaction with other non-enzymatic antioxidants (Forman et al. 2009). It is highly intriguing that supplementing Ascochloris spp. as an algal feed could drastically reduces the oxidative stress levels in the aquatic fishes as demonstrated in the current study. Similarly, other studies have reported that elevated GSH levels were observed in muscle and liver of Sparus aurata and Salmo salar fishes when fed with plant-protein diet (Sitjà-Bobadilla et al. 2005; Olsvik et al. 2011). This clearly suggests that plant-protein diets could be incorporated in the fish meals along with animal-based protein diets. In another study, it was observed that other than aquatic species, supplementation of Chlorella sp. and Spirulina fusiformis to mammalia (Swiss albino mice) showed elevated ratio of GSH/GSSG, reduced bacterial translocation and enhanced the defense mechanisms (Bedirli et al. 2009; Sharma et al. 2007).

\section{Glutathione-s-transferase (GST)}

GST is primarily responsible for detoxification of xenobiotic substances by conjugating it with endogenous reduced glutathione (GSH) (Jancova et al. 2010). GST activity in the muscle tissue extracts was significantly higher in the CF $\left(1.59 \pm 0.03\right.$ nmoles $\mathrm{mg}^{-1}$ protein) than in the $\mathrm{AF}\left(0.39 \pm 0.02 \mathrm{nmoles} \mathrm{mg}^{-1} \mathrm{protein}\right)$, respectively (Fig. 2b). As the microalgal cells were not found to be deformed or disrupted in the cultivation process, (Supplementary Fig. 2a), it was presumed that significant generation of any exogenous compounds were nullified during the microalgal growth and could have directly contributed in elevating the enzymatic response of GST in the AF. In contrary, commercial feed used in this investigation contained minute amounts of anti-oxidants (Astaxanthin), synbiotics, vitamins and minerals (Optimum aquarium food, Thailand). Detailed composition of the algal feed and the commercial feed is given in Table 1. But, it is not clearly known that the anti-oxidants incorporated in the commercial feed had any effect on reducing the generation of redox active substances during the metabolic growth of the fishes. Further molecular understanding on the anti-oxidants present in the Ascochloris spp. warrants the potential applicability of the microalga as an aqua feed. Others have reported that no significant difference in the GST levels was recorded in Clarias gariepinus and Dicentrarchus labrax when fed with fishmeal supplemented with microalgal species such as Spirulina 
Table 1 Compositional analysis of feeds g\% per kg dry matter

\begin{tabular}{lll}
\hline & Algal meal & Commercial meal \\
\hline Moisture & 8.56 & 10 \\
Ash & 5 & 13.56 \\
Protein & 20 & 28 \\
Lipid & 11 & 3 \\
Carbohydrate & 6 & 4 \\
Antioxidants & ND & 0.1 \\
Vitamins & ND & 2 (vitamin C and E) \\
Minerals premix & ND & 2 \\
\hline
\end{tabular}

$N D$ not determined

platensis, Chlorella vulgaris, Gracilaria spp., Ulva spp., Fucus spp., respectively (Raji et al. 2018; Peixoto et al. 2016). However, incorporation of animal protein sources, i.e., cricket meal and housefly maggot meal in the diets of Clarias gariepinus and Oreochromis niloticus resulted in higher GST levels than the fishmeal diets alone (Ogunji et al. 2007; Taufek et al. 2016). Consequently, the origin of protein source cannot be solely contribute for direct enzymatic reactions of GST and thus further investigation is needed for determining the toxicity levels of fish feed constituents inducing enzymatic responses.

\section{Superoxide dismutase (SOD) and catalase (CAT)}

Superoxide dismutase (SOD) functions in dismutation of two molecules of superoxide anion $\left(\mathrm{O}_{2}\right)$ to molecular oxygen $\left(\mathrm{O}_{2}\right)$ and hydrogen peroxide $\left(\mathrm{H}_{2} \mathrm{O}_{2}\right)$ (Fridovich 1995), whereas catalase (CAT) further helps in degradation of the generated hydrogen peroxide to water and molecular oxygen (Chance et al. 1952). Both these enzymes represent highest activity against reactive oxygen species and free radicals and reflect a rapid cellular metabolic rate. Kumar et al. (2014) reported that enzymatic and non-enzymatic antioxidant molecules present in microalgal strains scavenge free radicals and protect the muscle cells from oxidative stress when supplemented as fish feed. Higher catalase activity in $\mathrm{AF}\left(6.68 \pm 0.13 \mathrm{U} \mathrm{mL}^{-1}\right)$ than in $\mathrm{CF}$ (3.22 $\pm 0.11 \mathrm{U} \mathrm{mL}^{-1}$ ) clearly indicates the protective role of microalga Ascohloris spp. proving it as a viable alternative fish feed supplement along with the commercially available aquafeeds to a large extent. Similar observations were recorded with SOD, where microalga fed Clarias gariepinus effectively eradicated free radicals as evident from higher enzymatic response in the $\mathrm{AF}\left(5.24 \pm 0.04 \mathrm{U} \mathrm{mL}^{-1}\right)$ than the $\mathrm{CF}$ $\left(4.30 \pm 0.02 \mathrm{U} \mathrm{mL}^{-1}\right)$, respectively (Fig. 2c). Similar experimental observations were reported by others where olive flounde, Paralichthys olivaceus, orange-spotted grouper Epinephelus coioides and Cyprinus carpio involving dietary Chlorella vulgaris, laminarin and Chlorella sp., respectively, exhibited similar responses (Rahimnejad et al. 2017; Yin et al. 2014; Stara et al. 2014). Elevated SOD and CAT activities are also reported in Sprague-Dawley rats fed with marine algae, Pelvetia siliquosa (Lee et al. 2003). Hence, it can be preliminarily concluded that the microalga fed fishes exhibit better defense mechanism against free radicals as compared to the commercial feed-fed fishes.

\section{Lipid peroxidation}

Free radicals are highly unstable molecules responsible for attacking carbon-carbon double bonds of intact lipid molecules, extracting hydrogen and forming peroxyl radicals and hydroperoxides. Free radical mechanism is a self proliferating process and is majorly responsible for damaging cells (Yin et al. 2011), however the antioxidant responses nullify such effects of free radicals (Lesser 2006). The amount of malondialdehyde recorded in the $\mathrm{CF}$ and the $\mathrm{AF}$ were $1.90 \pm 0.01$ nmoles $\mathrm{g}^{-1}$ and $1.71 \pm 0.01$ of nmoles $\mathrm{g}^{-1}$, respectively (Fig. 2c). Lipid peroxidation levels were marginally lower in the AF than in the CF, respectively. This clearly demonstrates that the microalgal antioxidant molecules could successfully mitigate the reactive oxygen species and protect the cells in the $\mathrm{AF}$, whereas the commercial fishmeal had comparatively lower protective effects. This could be due to the degradation of bioactive molecules in commercial fish feed. Hence, 
microalga-based diet had enhanced defense mechanisms than the commercial fish meal. Prevention of lipid peroxidation by microalgae was also observed in large yellow croaker, Pseudosciaena crocea fed with astaxanthin and Haematococcus pluvialis than the control diets without microalga supplementation (Li et al. 2014). Similarly, Salmo salar fishes fed with macroalga Palmaria palmate also demonstrated lower level of lipid peroxidation than the control diets excluding seaweed (Wan et al. 2016). Besides, supplementation of antioxidants ( $\beta$-carotene, astaxanthin and lutein) extracted from microalga Spirulina platensis, Haematococcus pluvialis and Botryococcus braunii, respectively, to mammalian species (male Wistar rats) could significantly prevent lipid peroxidation levels by scavenging hydroxyl radicals and free radicals (Ranga Rao et al. 2010).

Statistical analysis for all the experimental parameters performed was found with $p$ values much less than 0.05 (level of significance) (Supplementary data 2) which is a strong evidence against null hypothesis. Therefore the null hypothesis is rejected proving that there is a significant difference between the algal feed and commercial feed on various parameters of the specimen under study.

\section{Conclusion}

Based on the biochemical and enzymatic responses of GSH, GST, SOD, CAT and LPO with Ascochloris spp., it clearly suggests that the microalga could be a prospective candidate in aquafeed formulations. However, other than the aquafeed, the acceptability of microalga diet by the fishes also depends on several collective factors such as palatability, absorption of nutrients, antioxidant potential, voluntary feed intake by test animals, age and stress physiology of animals, respectively. This study presents a preliminary assessment of the microalgal strain, Ascochloris spp. as an aquafeed supplement. Further investigation determining the optimum constitution of the alga biomass viz., powdery and granular, in the fish diets formulations aided with binders and other animal protein constituents will reveal the applicability of the microalgal species as a potential aquafeed supplement. Also, cellular and molecular investigations further warrant the physiological and metabolic adaptation of the fresh-water and marine-water fishes towards establishing microalgae as a potential supplement of the commercial aquafeeds.

Acknowledgements The authors are thankful to the Director, Sardar Patel Renewable Energy Research Institute, Gujarat, India, for supporting this research. The research work is financially supported by Department of Biotechnology, Govt. of. India with Grant No. BT/PR8991/PBD/26/392/2013.

Author contributions AKK is a principal scientist and he has designed, supervised the research work and performed critical refinement of manuscript. SS is an associate scientist responsible for large-scale outdoor microalgae cultivation and dissection and sampling of experimental fishes. DD is a research fellow and has performed the fish feeding, enzymatic experiments, data analysis. GD is a research fellow responsible for large-scale outdoor microalgae cultivation in photo bioreactors, raceway pond and harvesting algal biomass. ES and AP are scientific technical assistants and have performed the microalgae growth, enrichment and culturing experiments, species identification and lipid profiling. AK, DD and SS have written the manuscript. All the authors have read and approved the final manuscript.

\section{Compliance with ethical standards}

Conflict of interest The authors declare no conflict of interest.

Open Access This article is distributed under the terms of the Creative Commons Attribution 4.0 International License (http:// creativecommons.org/licenses/by/4.0/), which permits unrestricted use, distribution, and reproduction in any medium, provided you give appropriate credit to the original author(s) and the source, provide a link to the Creative Commons license, and indicate if changes were made.

\section{References}

Abdel-Warith AW, Younis ES, Al-Asgah NA (2016) Potential use of green macroalgae Ulva lactuca as a feed supplement in diets on growth performance, feed utilization and body composition of the African catfish, Clarias gariepinus. Saudi J Biol Sci 23:404-409

Akerboom TP, Sies H (1981) Assay of glutathione, glutathione disulfide, and glutathione mixed disulfides in biological samples. Methods in enzymology, vol 77. Academic Press, Cambridge, pp 373-382 
Appler HN (1985) Evaluation of Hydrodictyon reticulatum as protein source in feeds for Oreochromis (Tilapia) niloticus and Tilapia zillii. J Fish Biol 27:327-334

Becker EW (2004) Microalgae in human and animal nutrition. In: Richmond A (ed) Handbook of microalgal culture. Biotechnology and applied phycology. Blackwell Science, Oxford, pp 312-351

Bedirli A, Kerem M, Ofluoglu E, Salman B, Katircioglu H, Bedirli N, Yılmazer D, Alper M, Pasaoglu H (2009) Administration of Chlorella sp. microalgae reduces endotoxemia, intestinal oxidative stress and bacterial translocation in experimental biliary obstruction. Clin Nutr 28:674-678

Beers RF, Sizer IW (1952) A spectrophotometric method for measuring the breakdown of hydrogen peroxide by catalase. J Biol Chem 195:133-140

Bligh EG, Dyer WJ (1959) A rapid method of total lipid extraction and purification. Can J Biochem Physiol 37(8):911-917

Bradford MM (1976) A rapid and sensitive method for the quantitation of microgram quantities of protein utilizing the principle of protein-dye binding. Anal Biochem 72:248-254

Cahu CL, Infante JZ, Peres A, Quazuguel P, Le Gall MM (1998) Algal addition in sea bass (Dicentrarchus labrax) larvae rearing: effect on digestive enzymes. Aquaculture 161:479-489

Cha KH, Koo SY, Lee DU (2008) Antiproliferative effects of carotenoids extracted from Chlorella ellipsoidea and Chlorella vulgaris on human colon cancer cells. J Agric Food Chem 56:10521-10526

Chacon-Lee TL, Gonzalez-Marino GE (2010) Microalgae for "healthy" foods possibilities and challenges. Compr Rev Food Sci Food Saf 9:655-675

Chance B, Greenstein DS, Roughton FJ (1952) The mechanism of catalase action. I. Steady-state analysis. Arch Biochem Biophys 37:301-321

Close B, Banister K, Baumans V, Bernoth EM, Bromage N, Bunyan J, Erhardt W, Flecknell P, Gregory N, Hackbarth H, Morton D (1996) Recommendations for euthanasia of experimental animals: part 1. Lab Anim 30(4):293-316

Davies SJ, Brown MT, Camilleri M (1997) Preliminary assessment of the seaweed Porphyra purpurea in artificial diets for thicklipped grey mullet (Chelon labrosus). Aquaculture 152:249-258

Dubois M, Gilles KA, Hamilton JK, Rebers PT, Smith F (1956) Colorimetric method for determination of sugars and related substances. Anal Chem 28:350-356

Edwards DJ, Austreng E, Risa S, Gjedrem T (1977) Carbohydrate in rainbow trout diets. I. Growth of fish of different families fed diets containing different proportions of carbohydrate. Aquaculture 11:31-38

FAO-Food and Agricultural Organization (2012) State of the world fisheries. FAO Fisheries and Aquaculture Department: Food and Agriculture Organization of the United Nations, Rome

FAO-Food and Agricultural Organization (2018) The state of world fisheries and aquaculture 2018 - meeting the sustainable development goals

Folch J, Lees M, Sloane Stanley GH (1957) A simple method for the isolation and purification of total lipids from animal tissues. J Biol Chem 226:497-509

Forman HJ, Zhan H, Rinna A (2009) Glutathione: overview of its protective roles, measurement, and biosynthesis. Mol Aspects Med 30:1-12

Francis G, Makkar HP, Becker K (2001) Anti nutritional factors present in plant-derived alternate fish feed ingredients and their effects in fish. Aquaculture 199:197-227

Fridovich I (1995) Superoxide radical and superoxide dismutases. Annu Rev Biochem 64:97-112

Habig WH, Pabst MJ, Jakoby WB (1974) Glutathione $S$-transferases: the first enzymatic step in mercapturic acid formation. J Biol Chem 249:7130-7139

Henry M, Gasco L, Piccolo G, Fountoulaki E (2015) Review on the use of insects in the diet of farmed fish: past and future. Anim Feed Sci Technol 203:1-22

Jancova P, Anzenbacher P, Anzenbacherova E (2010) Phase II drug metabolizing enzymes. Biomed Pap Med Fac Univ Palacky Olomouc Czech Repub 154:103-116

Khan MI, Shin JH, Kim JD (2018) The promising future of microalgae: current status, challenges, and optimization of a sustainable and renewable industry for biofuels, feed, and other products. Microb Cell Fact 17:36

Kumar RR, Rao PH, Subramanian VV, Sivasubramanian V (2014) Enzymatic and non-enzymatic antioxidant potentials of Chlorella vulgaris grown in effluent of a confectionery industry. J Food Sci Technol 51:322-328

Kumar AK, Sharma S, Shah E, Parikh BS, Patel A, Dixit G, Gupta S, Divecha JM (2018) Cultivation of Ascochloris sp. ADW007enriched microalga in raw dairy wastewater for enhanced biomass and lipid productivity. Int J Environ Sci Technol 16:1-12

Laurens LM (2015) Summative mass analysis of algal biomass-integration of analytical procedures: laboratory analytical procedure (LAP) NREL

Lee S, Lee YS, Jung SH, Kang SS, Shin KH (2003) Anti-oxidant activities of fucosterol from the marine algae Pelvetia siliquosa. Arch Pharmacal Res 26:719-722

Lesser MP (2006) Oxidative stress in marine environments: biochemistry and physiological ecology. Annu Rev Physiol 68:253-278

Li M, Wu W, Zhou P, Xie F, Zhou Q, Mai K (2014) Comparison effect of dietary astaxanthin and Haematococcus pluvialis on growth performance, antioxidant status and immune response of large yellow croaker Pseudosciaena crocea. Aquaculture 434:227-232

McCord JM, Fridovich I (1969) Superoxide dismutase an enzymic function for erythrocuprein (hemocuprein). J Biol Chem 244:6049-6055

Muchlisin ZA, Siti-Azizah MN (2010) Preliminary study on the natural extenders for artificial breeding of African catfish Clarias gariepinus (Burchell, 1822). AACL Bioflux 3:119-124

Mustafa G, Wakamatsu S, Takeda TA, Umino T, Nakagawa H (1995) Effects of algae meal as feed additive on growth, feed efficiency, and body composition in red sea bream. Fish Sci 61:25-28 
Norambuena F, Hermon K, Skrzypczyk V, Emery JA, Sharon Y, Beard A, Turchini GM (2015) Algae in fish feed: performances and fatty acid metabolism in juvenile Atlantic salmon. PLoS One 10:e0124042

Ogunji JO, Nimptsch J, Wiegand C, Schulz C (2007) Evaluation of the influence of housefly maggot meal (magmeal) diets on catalase, glutathione $S$-transferase and glycogen concentration in the liver of Oreochromis niloticus fingerling. Comp Biochem Physiol A Mol Integr Physiol 147:942-947

Ohkawa H, Ohishi N, Yagi K (1979) Assay for lipid peroxides in animal tissues by thiobarbituric acid reaction. Anal Biochem 95:351-358

Olsen RL, Hasan MR (2012) A limited supply of fishmeal: impact on future increases in global aquaculture production. Trends Food Sci Technol 27:120-128

Olsvik PA, Torstensen BE, Hemre GI, Sanden M, Waagbo R (2011) Hepatic oxidative stress in Atlantic salmon (Salmo salar L.) transferred from a diet based on marine feed ingredients to a diet based on plant ingredients. Aquac Nutr 17:e424-e436

Olvera-Novoa MA, Domínguez-Cen LJ, Olivera-Castillo L, Martinez-Palacios CA (1998) Effect of the use of the microalga Spirulina maxima as fish meal replacement in diets for tilapia, Oreochromis mossambicus (Peters), fry. Aquac Res 29:709-715

Panserat S, Kolditz C, Richard N, Plagnes-Juan E, Piumi F, Esquerré D, Médale F, Corraze G, Kaushik S (2008) Hepatic gene expression profiles in juvenile rainbow trout (Oncorhynchus mykiss) fed fishmeal or fish oil-free diets. Br J Nutr 100:953-967

Park H, Lee CG (2016) Theoretical calculations on the feasibility of microalgal biofuels: utilization of marine resources could help realizing the potential of microalgae. Biotechnol J 11:1461-1470

Peixoto MJ, Salas-Leitón E, Pereira LF, Queiroz A, Magalhaes F, Pereira R, Abreu H, Reis PA, Gonçalves JFM, de Almeida Ozório RO (2016) Role of dietary seaweed supplementation on growth performance, digestive capacity and immune and stress responsiveness in European seabass (Dicentrarchus labrax). Aquac Rep 3:189-197

Radhakrishnan S, Bhavan PS, Seenivasan C, Shanthi R, Muralisankar T (2014) Replacement of fishmeal with Spirulina platensis, Chlorella vulgaris and Azolla pinnata on non-enzymatic and enzymatic antioxidant activities of Macrobrachium rosenbergii. J Basic Appl Zool 67:25-33

Rahimnejad S, Lee SM, Park HG, Choi J (2017) Effects of dietary inclusion of Chlorella vulgaris on growth, blood biochemical parameters, and antioxidant enzyme activity in olive flounder, Paralichthys olivaceus. J World Aquac Soc 48:103-112

Raji AA, Alaba PA, Yusuf I, Bakar NHA, Taufek NHM, Muin H, Alias Z, Milow P, Razak SA (2018) Fishmeal replacement with Spirulina Platensis and Chlorella vulgaris in African catfish (Clarias gariepinus) diet: effect on antioxidant enzyme activities and haematological parameters. Res Vet Sci 119:67-75

Ranga Rao A, Raghunath Reddy RL, Baskaran V, Sarada R, Ravishankar GA (2010) Characterization of microalgal carotenoids by mass spectrometry and their bioavailability and antioxidant properties elucidated in rat model. J Agric Food Chem 58:8553-8559

Ross D (1988) Glutathione, free radicals and chemotherapeutic agents: mechanisms of free-radical induced toxicity and glutathione-dependent protection. Pharmacol Therapeut 37:231-249

Sharma MK, Sharma A, Kumar A, Kumar M (2007) Spirulina fusiformis provides protection against mercuric chloride induced oxidative stress in Swiss albino mice. Food Chem Toxicol 45:2412-2419

Shimeno S, Hosokawa H, Takeda M (1978) The importance of carbohydrate in the diet of a carnivorous fish (yellowtail and carp). In FAO, Rome (Italy). Fisheries Dept. Symposium on Finfish Nutrition and Feed Technology. Hamburg (Germany, FR)

Sitjà-Bobadilla A, Peña-Llopis S, Gómez-Requeni P, Médale F, Kaushik S, Pérez-Sánchez J (2005) Effect of fish meal replacement by plant protein sources on non-specific defence mechanisms and oxidative stress in gilthead sea bream (Sparus aurata). Aquaculture 249:387-400

Stara A, Sergejevova M, Kozak P, Masojidek J, Velisek J, Kouba A (2014) Resistance of common carp (Cyprinus carpio L.) to oxidative stress after chloramine-T treatment is increased by microalgae carotenoid-rich diet. Neuro Endocrinol Lett 35:71-80

Taufek NM, Aspani F, Muin H, Raji AA, Razak SA, Alias Z (2016) The effect of dietary cricket meal (Gryllus bimaculatus) on growth performance, antioxidant enzyme activities, and haematological response of African catfish (Clarias gariepinus). Fish Physiol Biochem 42:1143-1155

Tsiplakou E, Abdullah MAM, Skliros D, Chatzikonstantinou M, Flemetakis E, Labrou N, Zervas G (2017) The effect of dietary Chlorella vulgaris supplementation on micro-organism community, enzyme activities and fatty acid profile in the rumen liquid of goats. J Anim Physiol Anim Nutr 101:275-283

Valente LMP, Linares F, Villanueva JLR, Silva JMG, Espe M, Escorcio C, Pires MA, Saavedra MJ, Borges P, Medale F, AlvarezBlazquez B (2011) Dietary protein source or energy levels have no major impact on growth performance, nutrient utilisation or flesh fatty acids composition of market-sized Senegalese sole. Aquaculture 318:128-137

Velasquez SF, Chan MA, Abisado RG, Traifalgar RFM, Tayamen MM, Maliwat GCF, Ragaza JA (2016) Dietary Spirulina (Arthrospira platensis) replacement enhances performance of juvenile Nile tilapia (Oreochromis niloticus). J Appl Phycol 28:1023-1030

Wan AH, Soler-Vila A, O'Keeffe D, Casburn P, Fitzgerald R, Johnson MP (2016) The inclusion of Palmaria palmata macroalgae in Atlantic salmon (Salmo salar) diets: effects on growth, haematology, immunity and liver function. J Appl Phycol 28:3091-3100

Yin H, Xu L, Porter NA (2011) Free radical lipid peroxidation: mechanisms and analysis. Chem Rev 111:5944-5972

Yin G, Li W, Lin Q, Lin X, Lin J, Zhu Q, Jiang H, Huang Z (2014) Dietary administration of laminarin improves the growth performance and immune responses in Epinephelus coioides. Fish Shellfish Immunol 41:402-406

\section{Publisher's Note}

Springer Nature remains neutral with regard to jurisdictional claims in published maps and institutional affiliations. 